\title{
Asuhan Keperawatan Jiwa: Pasien Resiko Perilaku Kekerasan
}

\author{
Deli Lita Anisa ${ }^{1}$, Arif Setiya Budi ${ }^{1}$, Suyanta ${ }^{1}$ \\ I'Program Studi Keperawatan, Poltekkes Kemenkes Semarang, Magelang, Jawa Tengah \\ Corresponding author: delilita95@gmail.com
}

\begin{abstract}
ABSTRAK
Latar Belakang: resiko Perilaku Kekerasan (RPK) adalah respon marah atau perilaku rentan dilakukan oleh seseorang dimana perilaku itu beresiko membahayakan diri sendiri, orang lain, maupun lingkungan sekitar. Ada dua faktor yang mempengaruhi resiko perilaku kekerasan yaitu faktor predisposisi dan faktor Presipitasi.

Tujuan: penelitian ini bertujuan untuk menggambarkan bagaimana asuhan keperawatan resiko perilaku kekerasan.

Metode: penelitian ini menggunakan metode kualitatif dengan menggunakan pendekatan proses keperawatan. Subyek dalam penelitian ini yaitu 1 klien Resiko Perilaku Kekerasan . Hasil: hasil penelitian ini merupakan hasil dari asuhan keperawatan jiwa resiko perilaku sosial melalui intervensi bina hubungan saling percaya, bantu klien mengungkapkan perasaan marahnya, bantu klien mengungkapkan tanda-tanda perilaku kekerasan yang dialaminya, diskusikan dengan klien perilaku kekerasan yang dilakukan, diskusikan dengan klien akibat negatif dari perbuatan yang dilakukan, diskusikan tentang cara mengungkapkan marah yang sehat.
\end{abstract}

Simpulan: pemberian asuhan keperawatan pada klien disesuaikan pada masalah dan respon klien.

Kata Kunci:

Resiko perilaku kekerasan; asuhan keperawatan; keperawatan jiwa.

\section{ABSTRACT}

Background: risk of Violent Behavior (RPK) is an angry response or vulnerable behavior carried out by someone where the behavior is at risk of endangering oneself, others, and the surrounding environment. There are two factors that influence the risk of violent behavior, namely predisposing factors and precipitation factors.

Purpose: this study aims to describe how nursing care risks violent behavior.

Methods: this study uses a qualitative method using a nursing process approach. The subjects in this study were 1 client at Risk for Violent Behavior.

Results: the results of this study are the result of mental nursing care at the risk of social behavior through interventions to build a trusting relationship, help clients express their angry feelings, help clients reveal signs of violent behavior they experience, discuss with clients violent behavior committed, discuss with clients the consequences negative consequences of the act, discuss how to express healthy anger.

Conclusion: the provision of nursing care to clients is adjusted to the client's problems and responses.

\section{Keywords:}

Risk of violent behavior, nursing care; mental health 


\section{PENDAHULUAN}

Kesehatan merupakan kondisi yang dialami seseorang bahwa orang itu sehat psikologis dan sosial dapat dilihat ketika menjalin hubungan interpersonal bisa memuaskan, emosional yang positif, punya konseptual diri yang positif, serta koping yang efektif (Videbeck, 2008). Gangguan jiwa merupakan merupakan suatu terjadinya perubahan pada tubuh yaitu pada jiwa dimana dapat menyebabkan terganggunya fungsi jiwa kemudian bisa menimbulkan sesuatu yang menyiksa pada seseorang saat berinteraksi dengan sosial (Depkes RI, 2010)

Menurut WHO memperkirakan dari seluruh orang di dunia terdapat 450 juta yang mengalami gangguan mental. Dimana perkiraan peluang penduduk yang akan mengalami gangguan jiwa pada usia-usia tertentu yaitu $25 \%$. Saat ini presentasi pada orang dewasa yang mengalami gangguan jiwa yaitu $10 \%$. Tahun 2010 Departemen Kesehatan dan WHO memperkirakan masalah gangguan jiwa yang ditemukan di dunia 450 juta. 2,5 juta atau $60 \%$ terjadi di Indonesia terdiri dari pasien resiko perilaku kekerasan, terutama pada laki-laki usia 15-44 tahun. (Hawari 2012).

Riset Kesehatan Dasar (Riskesdas) (2018), Pada penduduk Indonesia orang yang menderita gangguan jiwa berat prevalensinya $7 \%$ permil, prevalensi $9 \%$ gangguan mental emosional penduduk Indonesia. Di Pulau Bali terdapat pasien gangguan jiwa berat dengan presentase 10,5\%, itu menjadi kasus gangguan jiwa berat terbanyak yang ada di Indonesia. Terjadi peningkatan prevevalensi pada pasien gangguan jiwa, dibuktikan dengan data Riskesdas tahun 2013 yaitu 1,7\% per mil, gangguan mental emosional 6\%. Dan sekarang, gangguan jiwa berat naik menjadi 7\% per mil. (Kemenkes RI, 2018)

Dalam gannguan jiwa ada berbagai macam kasus, salah satunya yaitu Resiko Perilaku Kekerasan (RPK). Resiko Perilaku Kekerasan bisa diartikan sebagai seseorang yang memiliki perilaku menunjukkan bahwa orang itu bisa membahayakan dirinya, orang disekitar lingkungan, secara fisik, emosional, seksual, verbal (Sutejo, 2017). Perilaku kekerasan adalah keadaan berbahaya untuk diri klien itu sendiri ataupun orang disekitarnya (Maramis,2009). Perilaku kekerasan adalah respon terhadap marah, sering diekspresikan dengan berbagai perbutatan seperti mengancam, mencederai orang lain, merusak lingkungan sekitar, akibat dari tindakan ini akan timbul berbagai kerugian bagi dirinya, orang lain, dan lingkungan sekitar (Keliat,dkk, 2011).

Resiko Perilaku kekerasan yaitu bentuk perilaku tujuannya untuk melukai seseorang secara psikologis ataupun fisik. Perilaku kekerasan yaitu respon maladaptif dari kemarahan seseorang akibat tidak mampunya klien mengatasi stressor yang sedang dialami di lingkungan (Wulansari \& Sholihah, 2021). Menurut Direja (2011) Perilaku kekerasan (RPK) adalah rentang emosi berupa ungkapan kemarahan, diperlihatkan secara verbal, fisik di lingkungan sekitar.

Perilaku kekerasan adalah respon terhadap streesor yang dialami seseorang, respon ini menimbulkan kerugian kepada diri sendiri, orang lain. Seseorang yang mengalami perilaku kekerasan menunjukan perubahan perilaku seperti mengancam, tidak bisa diam, gelisah, intonasi suara keras, ekspresi tegang, agresif, nada suara tinggi , bergembira secara berlebih. Pada seseorang yang mengalami resiko perilaku kekerasan mengalami perubahan penurunan kemampuan dalam memecahkan masalah, orientasi terhadap waktu, tempat, orang , kegelisahan (Pardede, Siregar, \& Halawa, 2020).

Berbagai gejala dan tanda perilaku kekerasan dapat diidentivikasi, diobservasi oleh perawat yaitu : Raut muka memerah dan tegang, mengepalkan tangan, mata melotot, Berbicara kasar Suara meninggi, mengatupkan rahang dengan kuat, mengancam dengan secara verbal 
ataupun fisik, merusak barang atau beda, melempar benda milik orang lain, kemampuan mengontrol perilaku kekerasan rendah Muhith (2015).

\section{TUJUAN}

Tujuan dilakukannya penelitian ini untuk menggambarkan bagaimana asuhan keperawatan jiwa masalah resiko perilaku kekerasan.

\section{METODE}

Penelitian ini memakai metode kualitatif. Metode kualitatif merupakan metode yang akan dipakai dalam penelitian ini dengan cara pendekatan proses asuhan keperawatan yang mengacu pada asuhan keperawatan yang sudah dipilih yaitu Asuhan Keperawatan Jiwa dengan Risiko Perilaku Kekerasan. Menurut Stuart (2013) ada beberapa faktor yang mempengaruhi Resiko Perilaku Kekerasan yaitu : Faktor predisposisi meliputi faktor biologis, faktor genetic, faktor biokimia, dan faktor sosial kultural. Kemudian Faktor Presipitasi, akibat dari tidak terpenuhinya kebutuhan dasar dan ekonomi yang mencukupi sehingga timbul ekspresi diri, ketidakmampuan untuk mengomunikasikan sesuatu dengan keluarga, dan sulit untuk berdialog memecahkan masalah, memiliki perilaku kehidupan yang anti sosial. Penelitian ini dilakukan di Ruang Amarta RSJ Dr. Soerojo Magelang. Penelitian ini dilakukan tanngal 2 Maret 2021-4 Maret 2021. Dalam penelitian ini menggunakan satu responden yaitu $\mathrm{Tn}$. R yang berusia 20 tahun dan sudah bersedia menjadi responden dengan diagnosa keperawtan risiko perilaku kekerasan. Cara pengumpulan data dengan melakukan observasi pada pasien, mencari data rekam medis pasien.

\section{HASIL}

Dari hasil pengkajian pada Tn. R, bahwa klien mudah tersinggung karena perkataan orang lain dan tidak segan akan melukai orang yang memancing emosinya, klien mengatakan benci terhadap seseorang dan pernah menusuk temannya dengan pisau. Setelah dilakukan tindakan keperawatan $2 \times 24$ jam dengan intervensi bina hubungan saling percaya, bantu klien mengungkapkan marahnya, bantu klien mengungkapkan tanda-tanda perilaku kekerasan yang dialami, diskusikan dengan klien perilaku kekerasan yang dilakukan, diskusikan dengan klien akibat negatif dari perbuatan yang dilakukan, diskusikan tentang cara mengungkapkan marah yang sehat.

Setelah dilakukan Implementasi selama 2x24 jam klien mulai bisa membina hubungan saling percaya, bisa mengungkapkan perasaan marah, mulai bisa mengungkapkan tanda perilaku kekerasan yang dialami, bisa mengungkapkan perilaku kekerasan apa yang telah dilakukan , klien bisa mengerti akibat negatif dari perbuatan yang dilakukan, klien paham dan mengerti beberapa cara yag sehat untuk mengungkapkan kemarahannya.

Sesudah dilakukan penelitian dapat ditemukan hasil yang relevan berdasarkan sumber terkait pengelolaan asuhan keperawatan Tn. R dengan resiko perilaku kekerasan di RSJ Dr. Soerojo. Di dalam pembahasan ini berfokuspada pengkajian, diagnosa, intervensi, evaluasi yang terdapat pada asuhan keperawatan. Riwayat dirawatnya Tn. R dikarenakan klien sering tertawa sendiri, mudah marah, mengamuk, dan mengancam orang disekitarnya apabila keinginannya tidak terpenuhi

\section{PEMBAHASAN}

Tn. R berjenis kelamin laki-laki berusia 20 tahun, beragama islam, masih menjadi pelajar SMP. Klien masuk ke RSJ Dr. Soerojo dengan diagnosa resiko perilaku kekerasan. Alasan 
Tn. R masuk ke RSJ Dr. Soerojo dikarenakan klien sering tertawa sendiri, mudah marah, mengamuk, dan mengancam orang disekitarnya apabila keinginannya tidak terpenuhi.

Faktor yang membuat $\mathrm{Tn}$. $\mathrm{R}$ di diagnosis dengan resiko perilaku kekerasan dikarenakan sebelumnya klien pernah mengalami gangguan kejiwaan dan ini ketiga kalinya di rawat di RSJ, dan pada pengobatan sebelumnya kurang berhasil, beberapa bulan kemudian klien sering mengamuk dfan marah- marah.

Resiko Perilaku Kekerasan adalah salah satu diagnosa yang sering muncul paa pasien jiwa yang ada di Indonesia. Diharapkan bahwa setelah klien ditindak lanjuti oleh petugas kesehatan dengan

cara diberikan asuhan keperawatan didapatkan hasil yang maksimal dan masalah dapat teratasi. Sehingga dapat mengurangi kasus Resiko Perilaku Kekerasan.

Pada masalah keperawatan jiwa resiko perilaku kekerasan perencanaan yang dilakukan ada beberapa cara yaitu salah satunya dengan membina hubungan saling percaya yang dapat dikaji antara lain mengucapkan salam, memperkenalkan diri oleh perawat, menanyakan nama, panggilan yang disukai klien, menanyakan perasaan, masalah yang sedang dihadapi klien, menjelaskan tujuan lalu membuat kontrak interaksi, mendengarkan ungkapan klien dengan penuh perhatian.

Pelaksanaan adalah perwujudan atau pengetahuan dari rencana perawatan yang telah disebutkan meliputi tindakan yang dilakukan perawat, tindakan yang dilakukan pasien sendiri, dan tindakan kolaboratif dengan tim kesehatan lainnya.

Evaluasi adalah langkah penilaian dari pencapaian selama dilakukan penelitian yang bertujuan untuk pengkajian ulang keperawatan. Tahap Evaluasi adalah tahap akhir yang dicapai atau tahap keberhasilan yang menyajikan hasil akhir. Ketika mengevaluasi yang harus selalu diperhatikan yaitu keakuratan, kelengkapan, kualitas yang ada pada data tersebut, masalah pasien dapat teratasi atau tidak karena itu untuk menentukan intervensi akan tercapai atau tidak. Pada kasus Tn. R telah dilakukan implementasi selama $2 \times 24 j a m$ dan hasil maksimal masalah dapat teratasi dan harus tetap intervensi dipertahankan.

\section{SIMPULAN}

Berdasarkan dari penelitian studi kasus yang telah dikaji dapat disimpulkan bahwa kasus Tn. $\mathrm{R}$ dengan resiko perilaku kekerasan di RSJ Dr. Soerojo Magelang termasuk dalam masalah keperawatan yang terjadi karena faktor predisposisi yaitu riwayat gagguan jiwa, riwayat pengobatan, pernah mengalami pengalaman tidak menyenangkan, dan secara faktor genetik juga dipengaruhi karena kakek dari klien juga melakukan hal yang sama persis dilakukan klien dalam mengatasi masalah. Di dalam kasus $\mathrm{Tn}$. $\mathrm{R}$ tentang resiko perilaku kekerasan difokuskan agar pasien bisa membina hubungan saling percaya, bisa mengontrol perilaku kekerasan, mengertii dan mengidentifikasi perilaku yang dilakukan, dan dapat menyalurkan kemarahan dengan cara yang sehat.

\section{REFERENSI}

Depkes RI. (2010). Buku Pedoman Kesehatan jiwa. Jakarta : Depkes.

Sutejo.(2017) Konsep dan Praktik Asuhan Keperawatan Kesehatan Jiwa : Gangguan Jiwa dan Psikososial. Yogyakarta : PT. Pustaka Baru.

Maramis.2009.Catatan Ilmu Kedokteran Jiwa. Edisi 2. Surabaya : Airlangga.

Kelliat, Budi Anna. Akemat. Novy Helena. Heni Nurhaeni.2011. Keperawatan Kesehatan Jiwa Komunitas. Jakarta : ECG. 
Manurung, Y. R. (2021). Manajemen Asuhan Keperawatan Jiwa Pada Ny. A dengan Risiko Perilaku Kekerasan.

Anggit Madhani, A. (2021). Asuhan Keperawatan Jiwa Pada Pasien Dengan Resiko Perilaku Kekerasan (Doctoral dissertation, Universitas Kusuma Husada Surakarta).

Fadillah, F. (2021). Studi Kasus: Asuhan Keperawatan Jiwa pada Ny.R dengan Risiko Perilaku Kekerasan.

Husna,H., Sianturi, M. O., \& Pasaribu, R. (2021). Terapi Aktivitas Kelompok Stimulasi Persepsi Pada Pasien Risiko Perilaku Kekerasan.

Mare, M.N.S., Laia, D., Fadilah, F., Sikutiro, H., Lase, L, \& Manurung, R. (2021). Aplikasi Asuhan Keperawatan Jiwa pada Ny. T dengan Risiko Perilaku Kekerasan.

Septyaningtyas, R. A. (2019). Asuhan Keperawatan Pada Pasien Gangguan Jiwa Dengan Resiko Perilaku Kekerasan ( Doctoral dissertation, STIKes Kusuma Husada Surakarta)

Untari, S. N. (2021), Asuhan keperawatan jiwa pada pasien dengan perilaku kekerasan (Doctoral dissertation, Perpustakaan Universitas Kusuma Husada Surakarta)

Kandar, K., \& Iswanti, D. I. (2019). Faktor Predisiposis dan Prestipitasi Pasien Resiko Perilaku kekerasan. Jurnal Ilmu Keperawatan Jiwa, 2(3), 149-156.

Estika Mei Wulansari, E.(2021). Asuhan Keperawatan Jiwa Pada Pasien Dengan Resiko Perilaku Kekerasan Dirumah Sakit Daerah Dr Arif Zainuddin Surakarta ( Doctoral dissertation, Universitas Kusuma Husada Surakarta.

Malfasari, E., Febtrina R., Maulinda, D., \& Amimi, R. (2020). Analisis Tanda dan Gejala Resiko Perilaku Kekerasan pada Pasien Skizofrenia. Jurnal Ilmu Keperawatan Jiwa, 3(1), 65-74.

Iriyanto, D. R. (2021). Literature Review: Penerapan Komunikasi Terapeutik Pada Perawat (Doctoral dissertation, Sekolah Tinggi Ilmu Kesehatan Jayapura). 